\title{
PENGARUH VARIABEL OPERASI PADA PROSES MODIFIKASI PATI GARUT DENGAN METODE CROSS LINKING PENGGANTI TEPUNG TERIGU SEBAGAI BAHAN BAKU PADA INDUSTRI BAKERY
}

\author{
Putri Rakhmawati, Risa Dwi Octaviani, Herry Santosa *) \\ Jurusan Teknik Kimia, Fakultas Teknik, Universitas Diponegoro, \\ Jl. Prof. Soedarto, SH, Kampus Undip Tembalang, Semarang, Indonesia 50275
}

\begin{abstract}
Abstrak
Pati garut merupakan komoditas pangan lokal yang berpotensi dapat menggantikan tepung terigu pada berbagai peruntukkan. Kelebihan pati garut yaitu tidak adanya gluten dan nilai indeks glisemik yang rendah. Namun, pati garut memiliki kelemahan yaitu swelling power dan kelarutan yang tidak memenuhi kriteria. Pada penelitian ini, dilakukan usaha untuk mengubah pati garut menjadi bahan baku industri bakery dengan menggunakan metode cross linking. Tujuan dari penelitian ini ialah mengkaji pengaruh suhu reaksi, waktu reaksi, dan mengkaji pengaruh volume oleoresin, terhadap swelling power dan kelarutan. Untuk mencapai tujuan, penelitian ini melalui 3 tahapan : (1) Tahap karakterisasi pati garut, (2) Tahap modifikasi pati garut dengan metode Cross Linking untuk merubah sifat pati garut sesuai dengan spesifikasi yang memenuhi syarat sebagai bahan baku industry bakery, (3) Tahap uji hasil terhadap produk pati garut yang telah dimodifikasi berdasarkan swelling power dan kelarutan. Untuk memenuhi kriteria bahan baku industri bakery, proses cross linking terhadap pati garut lebih baik dilakukan pada suhu reaksi $40^{\circ} \mathrm{C}$, waktu reaksi 90 menit, dan volume oleoresin $0,3 \mathrm{ml}$.
\end{abstract}

Kata kunci: pati garut, oleoresin, cross linking, swelling power, kelarutan

\begin{abstract}
[Operating Variables Effects on Process Modification of Arrowroot Startch by Cross Linking Method for Substituting Wheat Flour as Bakery Industry Raw Material] Arrowroot starch is local food comodity that has potential for many use. The advantage of arrowroot starch are free gluten and low glisemic index. But, arrowroot starch has disadvantage swelling power and solubility doesn't criteria. In this study, an attempt is made to change the arrowroot starch raw material for bakery industry by using cross-linking methods. The purpose of this research is to study the effect of reaction temperature, reaction time, and volume gingerol of swelling power and solubility. To achieve the goal of research through three stages: (1) The characteristic of arrowroot, (2) The phase of modified arrowroot starch with method Cross Linking is done to change the properties of arrowroot starch in accordance with the specification qualify as bakery industry raw materials, (3) Analysis phase to modified arrowroot starch products which include swelling power and solubility. To achieve swelling power and solubility for raw material bakery industry, cross linking process to Arrowroot strach better are reaction temperature at 400C, reaction time at 90 minutes and oleoresin volum at 0,3 ml.
\end{abstract}

Keywords: arrowroot strach, oleoresin, cross linking, swelling power, solubility

\section{Pendahuluan}

Industri bakery di tanah air terus berkembang, mulai dari industri roti rumahan hingga outlet modern yang berstatus waralaba dari luar negeri. Pembuatan produk bakery, biasanya berbahan baku tepung terigu. Usaha mengatasi ketergantungan tepung terigu adalah

*) Penulis Korespondensi

E-mail: hersantos@undip.ac.id dengan mencari alternatif pengganti tepung terigu, baik yang bersifat substitusi sebagian ataupun seluruhnya.

Umbi garut (Maranta arundinaceae, Arrowroot, West Indian Arrowroot) merupakan salah satu pangan lokal yang merupakan tanaman berjenis umbi-umbian (Djafar, 2010). Diketahui bahwa, pati yang dibuat dari umbi garut tidak mengandung gluten. Bagi penderita autisme, kasein dan gluten tidak bisa dicerna dengan sempurna. Keunggulan pati garut yaitu 


\section{Teknik, 35 (1), 2014, 57}

nilai indeks glisemik yang rendah yaitu 14 (Marsono, 2002). Indeks glisemik merupakan ukuran yang menyatakan kenaikan gula darah setelah seseorang mengkonsumsi makanan yang bersangkutan. Namun pati garut memiliki kelemahan yaitu swelling power dan kelarutan yang tidak memenuhi kriteria. Maka perlu dilakukan usaha untuk meningkatkan nilai swelling power dan kelarutan dengan cara memodifikasi pati garut.

Modifikasi dimaksudkan sebagai usaha untuk merubah struktur molekul yang dapat dilakukan secara kimia, fisik, maupun enzimatis. Penelitian tentang modifikasi pati garut telah dilakukan. Diantaranya memodifikasi pati garut dengan metode dekstrinasi untuk bahan baku pembuatan MP-ASI (Sitorus, 2003), membuat pati resiten III dari pati garut (Gustiar, 2009). Penelitian-penelitian sebelumnya dilakukan untuk meningkatkan nilai guna pati agar dapat digunakan sebagai bahan baku pangan. Salah satu metode untuk memodifikasi pati yaitu metode cross linking.

Metode cross linking diperoleh dengan cara mereaksikan pati dengan senyawa bi- atau polifungsional yang dapat bereaksi dengan gugus $-\mathrm{OH}$ pada struktur amilosa atau amilopektin sehingga membentuk ikatan silang yang menghubungkan satu molekul pati dengan molekul pati lainnya. Jika pati terikat silang dipanaskan di dalam air, granula akan mengembang dan ikatan hidrogennya akan melemah namun ikatan silang tidak terpengaruh, sehingga granula pati yang mengembang dapat dipertahankan (Miyazaki, 2006). Metode ini dibuat dengan menambahkan cross linking agent. Cross linking agent yang digunakan yaitu oleoresin jahe. Oleoresin jahe mengandung gingerol, shogaol, zingerone, resin (Siswanto, 2013).

Pada penelitian ini, akan dilakukan suatu usaha memodifikasi pati garut dengan menggunakan metode cross linking. Tujuan dari memodifikasi pati garut yaitu untuk menentukan kondisi operasi meliputi suhu reaksi, waktu reaksi, dan volume oleoresin yang digunakan untuk mencapai nilai swelling power dan kelarutan sebagai bahan baku industri bakery.

\section{Bahan dan Metode Penelitian \\ Bahan dan Alat}

Bahan baku yang digunakan pada penelitian ini yaitu pati garut, aquadest, dan oleoresin jahe. Pati garut berasal dari Produk Kainara, Bekasi. Oleoresin jahe didapat dari CV Lansida, Yogyakarta. Alat yang digunakan reaktor tangki berpengaduk dan magnetic stirrer.

\section{Pelaksanaan Penelitian}

Penelitian dilakukan melalui 3 tahapan: tahap karakterisasi pati garut, tahap modifikasi cross linking, dan tahap uji hasil.

a. Tahap Karakterisasi Pati Garut
Tahap karakterisasi pati garut dimaksudkan untuk mengetahui komposisi dan sifat fungsional pangan dari pati garut sebelum proses modifikasi dilakukan.

b. Tahap Modifikasi Cross Linking

Tahap modifikasi cross linking bertujuan untuk merubah sifat pati garut yang memenuhi kriteria yang disyaratkan sebagai bahan baku industri bakery berdasarkan swelling power dan kelarutan.

c. Tahap Uji Hasil

Tahap uji hasil dimaksudkan untuk menganalisis sifat fungsional pati garut termodifikasi sehingga perubahan sifat fungsional sebelum dan sesudah dilakukan proses cross linking dapat diketahui.

Rancangan penelitian ini dapat disajikan dalam diagram blok (Gambar 2).

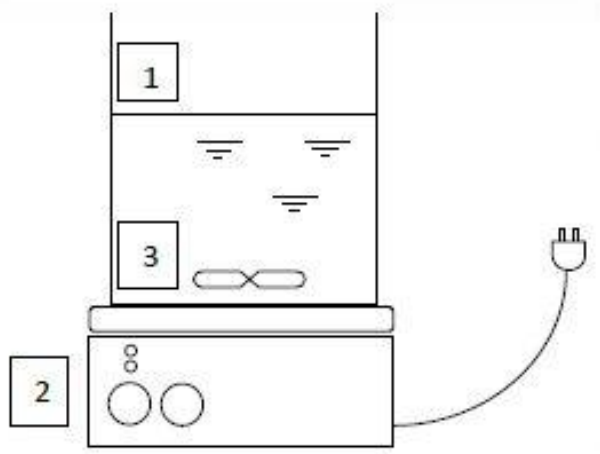

Gambar 1. Rangkaian alat percobaan modifikasi pati garut
Keterangan :
1. Reaktor berpengaduk
2. Magnetic Stirer
3. Stirrer

\section{Hasil dan Pembahasan \\ Karakterisasi Pati Garut}

Karakterisasi pati garut dimaksudkan untuk mengetahui komposisi swelling power dan kelarutan pati garut dengan menggunakan metode Leach (1959) sedangkan solubility di uji menggunakan metode Kaimuna (1967). Tujuan menganalisa swelling power dan kelarutan yaitu memperkirakan ukuran atau volume yang digunakan dalan proses produksi sehingga jika pati mengalami swelling power, wadah yang digunakan masih bisa menampung pati tersebut dan mengetahui suatu produk mudah di cerna dalam sistem pencernaan tubuh (Suriani, 2008).

Pada tabel 1, swelling power dan kelarutan pati garut lebih kecil dibandingkan tepung terigu. Pati garut diharapkan dapat mensubtitusi sebagian atau keseluruhan tepung terigu dalam pembuatan roti, cake, dan cookies. Maka diperlukan suatu usaha untuk meningkatkan nilai swelling power dan kelarutan pati garut agar mendekati nilai tepung terigu Cakra Kembar. 


\section{Teknik, 35 (1), 2014, 58}

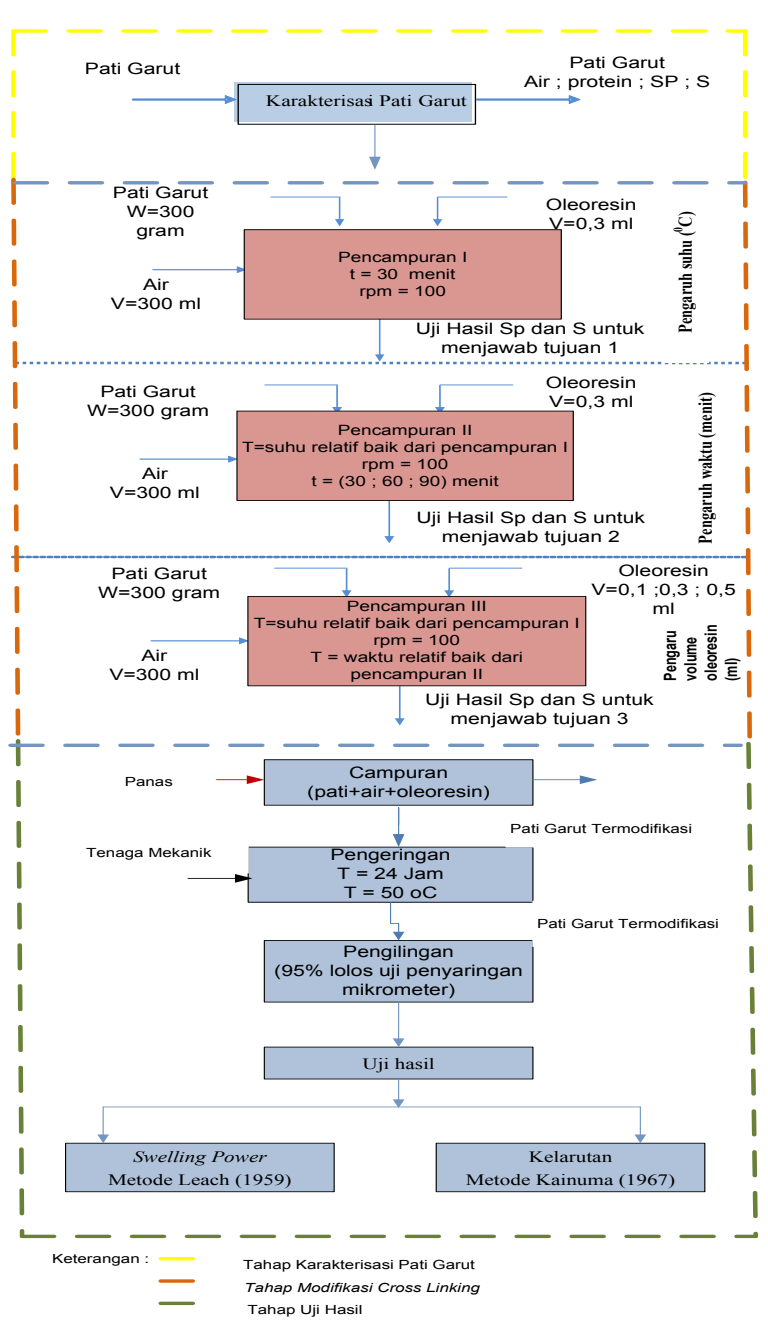

Gambar 2. Diagram blok rancangan penelitian

Tabel 1. Karakterisasi pati garut dan tepung terigu

\begin{tabular}{llcc}
\hline No. & \multicolumn{1}{c}{ Analisa } & $\begin{array}{c}\text { Pati } \\
\text { Garut }\end{array}$ & $\begin{array}{c}\text { Tepung } \\
\text { Terigu } \\
\text { Cakra } \\
\text { Kembar }\end{array}$ \\
\hline 1. & $\begin{array}{l}\text { Swelling power } \\
(\mathrm{g} / \mathrm{g})\end{array}$ & $4,75^{*}$ & $9,35^{* *}$ \\
2. & Kelarutan (\%) & $0,75^{*}$ & $1,35^{* *}$ \\
3. & $\begin{array}{l}\text { Protein kasar } \\
\text { (\%bk) }\end{array}$ & $0,62^{*}$ & 12,22 \\
4. & Air $(\%$ bk) & $15,85^{*}$ & 11,1 \\
5. & Gluten & 0,0 & - \\
6. & Kasein & 0,0 & - \\
\hline
\end{tabular}

penelitian sendiri

${ }^{* *}$ Wijayaningrum,2011

\section{Penentuan Suhu Reaksi Relatif Baik}

Untuk menentukan suhu relatif baik, percobaan dilakukan pada kondisi tetap: berat pati 300 gram, volume air $300 \mathrm{ml}$, volume oleoresin $0,3 \mathrm{ml}$, kecepatan putaran $100 \mathrm{rpm}$ dan waktu 30 menit. Di setiap akhir percobaan dilakukan uji hasil terhadap swelling power dan kelarutan. Hasil selengkapnya dapat dilihat pada Tabel 2.

Tabel 2. Pengaruh suhu terhadap nilai swelling power dan kelarutan

\begin{tabular}{|c|c|c|c|}
\hline \multirow[b]{2}{*}{ No. } & \multirow[b]{2}{*}{ $\pm T\left({ }^{0} \mathrm{C}\right)$} & \multicolumn{2}{|c|}{ Respon } \\
\hline & & $\begin{array}{c}\text { Swelling } \\
\text { Power }\end{array}$ & Kelarutan \\
\hline 1 & 30 & 8,3 & 0,72 \\
\hline 2 & 40 & 10,87 & 0,77 \\
\hline 3 & 50 & 5,85 & 0,6 \\
\hline 4 & 70 & 4,65 & 0,35 \\
\hline
\end{tabular}

Pada tabel 2 diperoleh data bahwa ketika suhu dinaikkan maka akan meningkatkan nilai swelling power dan kelarutan pati hasil proses cross linking. Hal ini dikarenakan kenaikan suhu (pemanasan) mengakibatkan ikatan hidrogen merenggang, sehingga air mudah terimbibisi ke granula pati yang menyebabkan granula pati mengembang. Mengembangnya granula pati ditunjukkan dengan meningkatnya nilai swelling power dan kelarutan dari pati tersebut (Feros dan Abid, 2008). Tahapan proses reaksinya seperti yang ada pada Gambar 3 .

Pada suhu $50^{\circ} \mathrm{C}$, oleoresin mulai terdegradasi sehingga oleoresin yang bereaksi membentuk pati termodifikasi semakin kecil (Battharai, 2001). Hal ini, ditunjukkan dengan nilai swelling power dan kelarutan yang menurun.

Dari tabel 2, untuk mendapatkan nilai swelling power dan kelarutan mendekati kriteria Tepung Terigu Cakra Kembar, proses cross linking lebih baik dilakukan pada suhu operasi $40^{\circ} \mathrm{C}$.

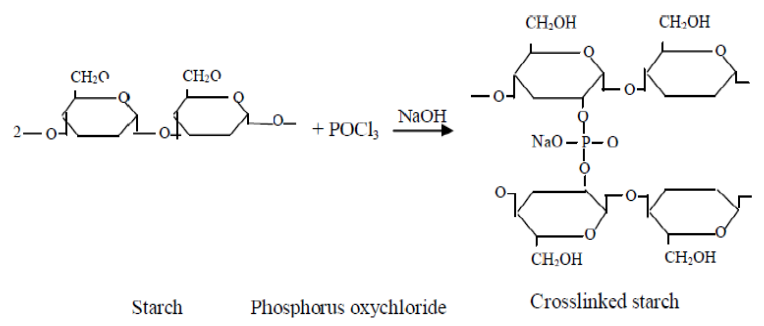

Gambar 3. Reaksi cross-linking pada pati (Miyazaki, 2006)

\section{Penentuan Waktu Relatif Baik}

Untuk menentukan waktu relatif baik, percobaan dilakukan pada kondisi tetap: berat pati 300 gram, volume air $300 \mathrm{ml}$, volume oleoresin $0,3 \mathrm{ml}$, kecepatan putaran $100 \mathrm{rpm}$, dan suhu relatif baik dari percobaan pertama yaitu $40^{\circ} \mathrm{C}$. Di setiap akhir percobaan dilakukan uji hasil terhadap swelling power dan kelarutan. Hasil selengkapnya dapat dilihat pada Tabel 3. 


\section{Teknik, 35 (1), 2014, 59}

Tabel 3. Pengaruh waktu terhadap nilai swelling power dan kelarutan

\begin{tabular}{cccc}
\hline & & \multicolumn{2}{c}{ Respon } \\
\cline { 3 - 4 } No. & \multirow{2}{*}{ (menit) } & $\begin{array}{c}\text { Swelling } \\
\text { Power }\end{array}$ & Kelarutan \\
\hline 1 & 30 & 10,87 & 0,77 \\
2 & 60 & 7,3 & 0,79 \\
3 & 90 & 9,3 & 0,78 \\
\hline
\end{tabular}

Pada Tabel 3, dapat diketahui bahwa lamanya waktu operasi akan mengakibatkan meningkatnya nilai swelling power dan menurunnya nilai kelarutan. Pada modifikasi pati garut dengan metode crosslinking, semakin lama waktu reaksi, maka semakin banyak kadar amilopektin yang bereaksi dengan oleoresin. Amilopektin memiliki sifat merangsang terjadinya proses mekar dalam produk makanan (HeeJoung An, 2005). Ini ditunjukkan dengan meningkatnya swelling power.

Nilai kelarutan yang menurun dikarenakan oleoresin yang bereaksi dengan pati mengakibatkan terbentuknya jaringan pada molekul pati yang berlebihan. Sehingga air sulit terimbibisi ke dalam granula pati (Siswanto, 2013). Dari Tabel 3, untuk memperoleh swelling power dan kelarutan mendekati kriteria Tepung Terigu Cakra Kembar, proses cross linking dilakukan selama 90 menit.

\section{Penentuan Volume Oleoresin Relatif Baik}

Untuk menentukan volume oleoresin relatif baik, percobaan dilakukan pada kondisi tetap: berat pati 300 gram, volume air $300 \mathrm{ml}$, kecepatan putaran
$100 \mathrm{rpm}$, dan suhu relatif baik dari percobaan pertama yaitu $40^{\circ} \mathrm{C}$ dan waktu relatif baik yaitu 90 menit. Di setiap akhir percobaan dilakukan uji hasil terhadap swelling power dan kelarutan. Hasil selengkapnya dapat di lihat pada Tabel 4.

Tabel 4. Pengaruh Volume Oleoresin terhadap Nilai Swelling power dan Kelarutan

\begin{tabular}{cccc}
\hline & \multirow{2}{c}{ Respon } \\
\cline { 3 - 4 } No. & $\begin{array}{c}\text { Volume } \\
\text { Oleoresin(ml) }\end{array}$ & $\begin{array}{c}\text { Swelling } \\
\text { Power }\end{array}$ & Kelarutan \\
\hline 1 & 0,1 & 7,1 & 0,79 \\
2 & 0,3 & 9,3 & 0,78 \\
3 & 0,5 & 3,7 & 0,68 \\
\hline
\end{tabular}

Pada Tabel 4, ketika volume oleoresin ditambahkan, akan terjadi kenaikan swelling power. Namun untuk penambahan volume oleoresin berlebih maka terjadi penurunan swelling power yang signifikan, dan nilai kelarutan yang menurun. Hal ini dikarenakan senyawa yang terdapat pada oleoresin yang dapat beraksi dengan gugus $-\mathrm{OH}$ pada struktur amilosa dan amilopektin, dapat membentuk ikatan silang atau jembatan yang menghubungkan satu molekul pati dengan pati lainnya. Dengan adanya ikatan silang ini, maka akan memperkuat ikatan hidrogen pada rantai pati (Februadi bastian, 2011). Ini ditunjukkan dengan meningkatnya nilai swelling power. Namun kelarutan menurun terjadi karena terbentuknya ikatan hidrogen yang rapat sehingga air sulit terimbibisi ke dalam granula pati.

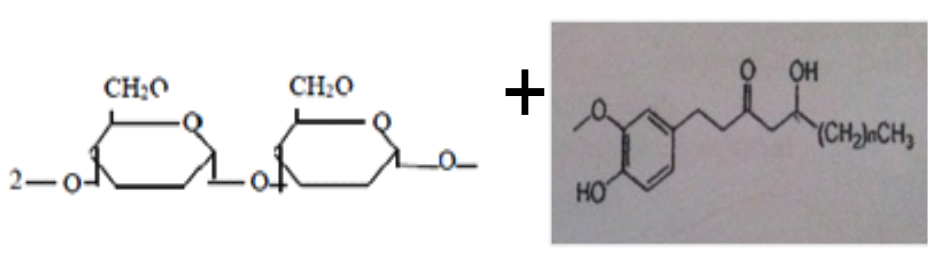

Pati Oleoresin

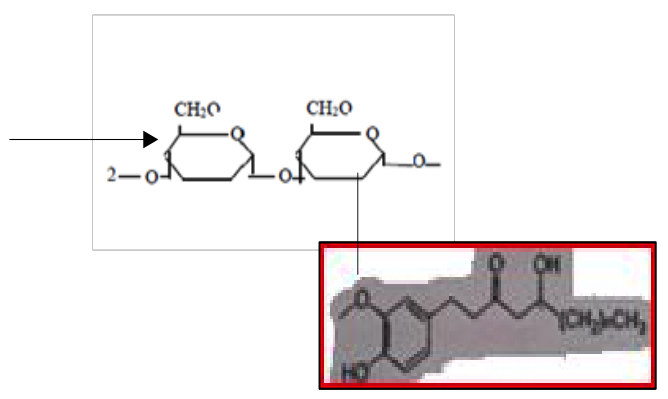

Pati Termodifikasi

Gambar 4. Reaksi Cross Linking Tepung Garut dengan Oleoresin

Penurunan nilai swelling power dan kelarutan pada pati termodifikasi diikuti dengan meningkatnya interaksi antara rantai pati dengan senyawa oleoresin. Ditambah lagi molekular inter dan intra ikatan $\mathrm{H}$ pada rantai pati menjadi lebih rapat dan strukturnya lebih dekat yang mengakibatkan molekul air sulit untuk masuk ke dalam granula pati (Kaur et al., 2004, Kavitha et al., 1998). Dari Tabel 4, untuk memperoleh swelling power dan kelarutan mendekati kriteria
Tepung Terigu Cakra Kembar, proses cross linking lebih baik dilakukan dengan penambahan $0,3 \mathrm{ml}$ oleoresin tiap 300 gram pati garut.

Pada kondisi operasi suhu reaksi $40^{\circ} \mathrm{C}$, waktu reaksi 90 menit dan volume oleoresin $0,3 \mathrm{ml}$ nilai swelling power dan kelarutan pati garut mendekati nilai swelling power dan kelarutan pada tepung terigu Cakra Kembar. 


\section{Teknik, 35 (1), 2014, 60}

\section{Kesimpulan}

Pati garut dapat ditingkatkan nilai swelling power dan kelarutan dengan menggunkan proses cross linking. Proses cross linking lebih baik dilakukan pada kondisi operasi suhu reaksi $40^{\circ} \mathrm{C}$, waktu reaksi 90 menit dan volume oleoresin $0,3 \mathrm{ml}$ nilai swelling power dan kelarutan pati garut mendekati nilai swelling power dan kelarutan pada tepung terigu Cakra Kembar.

\section{Ucapan Terima Kasih}

Ucapan terima kasih disampaikan kepada Laboratorium Dasar Teknik Kimia Universitas Diponegoro, atas kontribusinya sebagai tempat penelitian ini.

\section{Daftar Pustaka}

Bastian, F. (2011). Teknologi Pati dan Gula. Hibah Penulisan Buku Ajar Bagi Tenaga Akademis UNHAS. Universitas Hasanudin.

Battharai.,Tran,V.H., and Duke,C.C. (2001). Stability og Ginger and Shogaol in Simulated gastric and Intestinal Fluids. Pharmaceutical and Biomedical Analysis. 2001, vol.45, pp.648-653.

Djaafar, T.F.,Sarijiman dan Arlyna B.Pustika. (2010). Pengembangan Budi Daya Tanaman Garut dan Teknologi Pengolahannya untuk Mendukung Ketahanan Pangan. Laporan Kegiatan. Yogyakarta: Balai Pengajian Teknologi Pertanian

Feros, A and Abid. (2008). Studies On Swelling and Solubility of Modified Strach from Taro(Colocasia Escelenta):Effect of $\mathrm{pH}$ and Temperature. University of Karachy: Pakistan, Departement of Food Science and Technology.

Gustiar,H. (2009). Sifat Fisiko-Kimia dan Indeks Glisemik Produk Cookiest Berbahan Baku Pati Garut (Maranta arundinacea L.) Termodifikasi. Skripsi. Fakultas Teknologi Pertanian, Institut Pertanian Bogor.

Hee-Joung An. (2005). Effects of Ozonation and Addition of Amino acids on Properties of Rice Starches. A Dissertation subbmitted to Graduate Faculty of the Lousiana state
University and Agricultural and Mechanical College.

Kaur, L.,Singh,N.and Singh,J. (2004). Factors Influencing The Properties of Hydroxypropylated Potato Straches. Carbohyd Polym, 55,211-223.

Kavitha et al. (1998). Modified Straches. African Journal of Biotechnology. 1998, vol 5,pp.917920.

Leach, H.W, Mc Cowen L.D and Schoch, T.J., (1959). Structure of The Starch granules. In: swelling and solubility patterns of various straches. Cereal Chem 36:534-544.

Marsono,Y. (2002). Indeks Glisemik Umbi-Umbian. Makalah Seminar Nasional Industri Pangan, Perhimpunan Ahli Teknologi Pangan Indonesia (PATPI).

Miyazaki, Megumi, Pham V.H., Tomoko M., and Naofumi M. (2006). Recent Advances in Application of Modified Straches for Breadmaking.Trend in Food Science\&Tecnology,pp.591-599

Pratiwi,R. (2008). Modifikasi Pati Garut (Marantha arundinacea) dengan Perlakuan Siklus Pemanasan Suhu Tinggi-Pendinginan (Autoclaving-Cooling Cycling) untuk Menghasilkan Pati Resisten Tipe III. Skripsi. Fakultas Teknologi Pangan,Institut Pertanian Bogor

Sitorus,S.R. (2003). Pembuatan Biskuit untuk Makan Sapihan dari Pati Garut (Maranta arundinaceae L.). Skripsi. Fakultas Teknologi Pertanian, Institut Pertanian Bogor.

Siswanto dan Manurung,T. (2013). Modifikasi Tepung dari Umbi Gadung menggunakan Ekstrak Jahe sebagai Bahan Makan Fungsional. Jurnal Teknologi Kimia dan Industri, vol.2, no.2:181-191.

Wijayaningrum,Rustanti dan Selfienna Ferdiani. (2011). Modifikasi Sifat Psikokimia dan Rheologi Ubi Kayu Berbasis Kombinasi Perendaman dengan Garam dan Hidrolisa Menggunakan Asam Laktat untuk Bahan Baku Produk Mie. Skripsi. Department of Chemical Engineering, Diponegoro University. 